\title{
Systemic Functional Linguistics (SFL) as Sociolinguistic and Sociological Conception: Possibilities and Limits of Theoretical Framework
}

\author{
Mariia Rubtcova (Corresponding author) \\ Department of Social Management and Planning, Faculty of Sociology, Saint Petersburg State University, Russia \\ E-mail: abc33@yandex.ru \\ Oleg Pavenkov \\ Department of Media Communications, Saint-Petersburg State Institute of Film and Television, Russia
}

Irina Khmyrova-Pruel

Department of Cultural Studies, Aesthetics and Philosophy of Culture, Institute of Philosophy, Saint-Petersburg State University, Russia

Tatiana Malinina

Faculty of Sociology, Department of Social Analyses and Mathematical Methods in Sociology, Saint-Petersburg State University, Russia

Irina Dadianova

Department of Information Systems \& Multimedia, Faculty of Information Technologies, Saint-Petersburg State Institution of Culture, Russia

Received: 08-12-2015

Accepted: 10-03-2016

Advance Access Published: March 2016

Published: 01-05-2016

doi:10.7575/aiac.ijalel.v.5n.3p.272

URL: http://dx.doi.org/10.7575/aiac.ijalel.v.5n.3p.272

\begin{abstract}
The paper aims at examining possibilities and limits of Systemic functional linguistics theoretical framework. Ideologically SFL concept was associated with the ideas of social justice and equality, the building of the society of equal opportunities through the educational system. The most interesting ideas arose when the SFL representatives thought about the development of English as a native language and were connected with the overcoming of class distinctions. The current version - genre-based approach - has serious limits. The desire of a genre-based approach to the systematization of genres carries a risk of cultural contradictions and conflict of cultures. However, the basic theoretical SFL principles are still in the stage of formation, as SFL researchers seek to avoid some rigidity of the classical institutional (genre) approach, which is in contradiction with the principles of diversity. The founder M. Halliday offered ideas for the organization of a flexible approach based on International English that may become World Englishes, developing in order to adapt to the meanings of other cultures. Therefore, an SFL approach still needs some alterations to spread outside the Western world and conform to the new culture for it. Besides, we can think about proposals of Halliday's supporters to develop the own version of English for non-Western countries, considering its culture and mentality.
\end{abstract}

Keywords: Sociolinguistics, Systemic functional linguistics (SFL), World Englishes, cultural differences, the English language spread

\section{Introduction}

Sociolinguistics is a discipline that establishes regular compliances between language and social structures (e.g. Bell, 1980:41-42). The specific field of Sociolinguistics might not be easily defined because it is an interdisciplinary approach that attempts to combine the sciences studying the language and society. However, during the historical development sociolinguistics has become more linguistic discipline than sociological. In result, one sociolinguist can think that the main task of sociolinguistics is the creation of a theory of language use, but another sociolinguist may see sociolinguistics as a whole "linguistics". (Bell, 1980:38), which can show mainly the anti-Chomskian tradition of Sociolinguistics.

Under the influence of a similar division in sociology, sociolinguistics is divided into macro and micro level. Sociology had an impact on sociolinguistics as follows. Originally Marx's conflict model was apprehended in expanded Max Weber's interpretations (Kerswill, 2007:51). "Weber saw people as having differing 'life chances' because of differences in skills, education and qualifications. In a capitalist society, 'status' not directly derived from Marxian 'class' must be recognized, and this leads to differences in what Weber called 'styles of life', marked by such things as 'housing, dress, manner of speech, and occupation" (Giddens, 2001: 285). According to Kerswill, by the 1960s Weber's notion of 'status' would become central to sociolinguists. An example is Labov's concern with the social differentiation of phonetic and grammatical features in speech communities (Kerswill, 2007:52). This studying of status and speech 
community (micro level) defined sociolinguistics`start from the micro level, from micro sociology because Max Weber is considered the classical representative of microsociological tradition (Vorontsov \& Gromov, 1996).

In the 1950s-1960s functionalism starts prevailing in sociology. Talcott Parsons (1952) created this conception as an attempt to unite Weber and Durkheim's ideas (Vorontsov \& Gromov, 1996). As in sociolinguistics, Malinovsky`s work also had an impact on the development of a sociological functionalism (Blauberg \& Yudin, 1965). As a result, according to Kerswill, Labov's adoption of «status» actually came through his reading of functionalist sociologists in the 1950s, particularly Talcott Parsons (Kerswill, 2007:52). Parsons had the strong desire to create the general theory of society in which all elements are interrelated and that together they form a unified entity (Parsons, 1952). This theory received the name «structural functionalism». The creation of the general theory of society in sociology belongs to the sphere of macrosociology; so the dynamics of the development of Labov's views can be interpreted as a transition from the «micro» to the «macro» level. Thus, division into «micro» and «macro» level gradually was established in sociolinguistics.

It is clear that the division into macro and micro level is not a native tradition for sociolinguistics. Therefore, some authors ignore it because it is not linguistic in principle (e.g. Geeraerts et al., 2010) or seek to avoid it as inappropriate to the more flexible and changeable present-day reality (e.g. Blommaert, 2010). We will not discuss now the legitimacy of such division. We only briefly confine review what can be understood as the macro - and the micro-levels in sociolinguistics.

Macro-sociolinguistics studies large-scale processes and the relations that take place in language and can be caused by the social factors to a varying degree. These processes and the relations can characterize society in general or rather big groups of people: social groups, ethnic groups etc. For example, the study of the social differentiation of language would correspond to the macro level, which can say how a national language is distributed in different social groups of native speakers and migrants (Bell, 1980). Macro-sociolinguistics can be involved in considering many sociopolitical factors of language such as standardization and ideology, media discourse, the position of multilingual societies, educational policy and practice, language policy and planning (Llamas et al., 1996:40). Microsociolinguistics focuses on a language in a specific intragroup/intracommunity use. A micro-sociolinguistic analysis may describe the ways in which patterns of discourse vary, influenced by such things as the situation, communicative function, region, ethnicity, gender and social class (Llamas et al., 1996:41).

In the current study we will consider one of macro macrosociolinguistics concepts - Systemic functional linguistics (SFL) - and examine its social and ideological roots and limits. SFL concept was associated with the ideas of social justice and equality, equal opportunities. However, the changing role of English and its world-wide spread led to constant increase diversity problems, which is critical for a classic institutional approach. Many supporters of CLIL and bilingual education reflected on this problem and recognized the diversity need, for instance Cummins (1986, 2000). However, it is difficult to find in the Cummins' work the recognition of the institutional and genre diversity, rather he suggests that it is possible to promote and develop a genre in different languages, and experience will help in the development of all the differences and diversity in the future. SFL ideologies (e.g. Veel, 1997:163-165) see the problem. They tried to rebuild SFL pedagogy and put it on the modern philosophy of science bases. For example, R. Veel attracts Latour philosophy (see also: Latour \& Woolgar, 1986). So, it is possible to see some attempts to reconstruction SFL concept to recognize a greater diversity (Veel, 1997; Halliday: 2003). However, while the philosophically oriented SFL ideologists (e.g. Halliday: 2003) sought a new foundation that could save the idea of social justice and equality, they are also faced with the pressure of practitioners.

Within practical use, the concept was influenced by the many stakeholders who expect a relatively simple solution to promote English in the economic and political order. In this neo-liberal variant, SFL has a risk to be a tool to achieve competitive advantage in global markets.

The research questions are following:

What is the link between SFL and other ideological directions (Marxism, Vygotsky's theory) and their mutual coordination?

Are there any ideological, theoretical or philosophical limits that do not allow to implement the SFL-based conceptions in non-Western countries?

\section{Methodology and Data Collection}

Data comes from the papers of the analyzed scientific direction. The researchers use a dialectic method of the analysis of theoretical framework (Hegel) which allows revealing possibilities and limits of the theoretical concept. In addition, the researchers involve institutional approach in Berger and Lukman's statement. This approach puts emphasis on some negative manifestations of fixing/establishing of institutional structures.

\section{Results}

\subsection{SFL as a sociolinguistics conception. SFL place among sociological theories}

Labov thought about the close coordination between sociology and sociolinguistics (Labov, 1972). He was convinced that sociolinguistics can borrow survey methods and a wide range of concepts of social sciences but also the other way round (Labov, 1972:122). However, his ideas were not realized adequately as both sciences developed independently. Only a few factors, for example the growth of interest in discourse analysis, forced sociology to draw on linguistics in the development of new methodologies. 
In general, then, the theoretical frameworks of the two disciplines are not coordinated and actually non-readable from both sides. In this regard, there is a question as whether there is any opportunity to establish the interrelation between Parsons's (1952) "structural functionalism" and Systemic functional linguistics of Halliday.

Halliday`s Systemic functional linguistics is essentially a sociolinguistic conception:

the term social .. is meant to suggest two things simultaneously. One is "social" used in the sense of the social system, which I take to be synonymous with the culture. So when I say "social-semiotic", in the first instance, I am simply referring to the definition of a social system, or a culture, as a system of meanings. But I also intend a more specific interpretation of the word 'social', to indicate that we are concerned particularly with the relationships between language and social structure, considering the social structure as one aspect of the social system. (Halliday \& Hasan 1985: 4)

Sociolinguistics has also been defined as "the relationships between language and social structure" (Bell, 1980:41-42). The same idea can also be found in the following quotation:

Functional linguistics in concerned with explaining language in relation to how it is used - an explanation which ultimately depends on the development of a model of language in tandem with a model of social context so that one informs the other in relation to this enterprise. It is probably most appropriate to use the term functional sociolinguistics for research in which a functional model of language is strongly implicated in the design of a model of the social (Martin \& Williams, 2004: 120)

Parsons's "structural functionalism" is the general concept of society which describes all spheres of its activity, beginning from structure of social action to the societal level uniting institutional structure (Parsons, 1952). Both Parsons's and Halliday's theories use the terms: system, structure, functions, social action and role.

However, despite the fact that they have the common roots in Bronislav Malinovsky's doctrine (e.g. Halliday \& Hasan, 1985: 5) and follow the key concept of "functions", their origin, generally speaking, is different. SFL has accurately expressed roots in Marxism, which is impossible to say about Parsons's theory, which apprehended Marxism critically (e.g. Parsons, 1952). SFL had to accept a critical role that connected with ideas of social justice:

While in the 1950s Bernstein was troubled by issues of disadvantage when observing how workingclass children performed badly in London schools, Halliday, teaching at Cambridge, was an active participant in the Linguistics Group of the British Communist Party, and like his colleagues he had a passion to use his linguistics to make a difference in exploring the nature of social experience and in addressing questions of equity and social justice (Christie and Martin, 2009: 4).

Of course, this is a soft version of Marxism and it may be based on «Economic \& Philosophical Manuscripts of 1844» by Marx (1959), which have been popular in Europe since World War II. In particular, the researchers see, it means that systemic functional linguistics (SFL) (and the CLIL pedagogy based on it) from the beginning set goals for internationalization and open access to knowledge (include scientific) for all. In contrast, Parsons, to a great extent, was inclined to establish a social structure as a stable reality, but with no intention to change it (Parsons, 1952). The researchers can assume that in an initial stage of SFL formation it was an original sociological conception, which in itself can be a subject of research. The sociological aspect of SFL, first, is concentrated on studying language, but not only, as it assumes work with institutes of education, families and migrants, with the purpose of influencing policy, owing to its Marxist origin. Mainstream sociology does not know yet such a conception that successfully would combine Marxism with functionalism and thus has the practical development in education allowing to reach real visible results.

\subsection{The Limits of SFL as kind of institutional approach}

In the Australian period, pro-Marxist ideas of SFL mostly have been removed or changed. Some consequences of these changes can be seen in the debate between Michael Halliday and Anna Wierzbicka. Unfortunately, the description of the discussion remained only in the interpretation of Wierzbicka. Anna Wierzbicka submitted an article in Sydney Linguistic Circle. The article was about linguistic differences between English and Polish. She came to the center in full confidence that the article was accepted positively. However, she was stopped by Halliday questions:

My claims were challenged by Michael Halliday - not on empirical grounds but from a methodological standpoint. Is it justified, he asked, to link individual linguistic phenomena with nonlinguistic aspects of culture directly? He acknowledged that in some cases direct links do seem to exist, but he was inclined to confine such cases to the lexicon. As far as the grammar is concerned, he was more cautious. He agreed that, for example, the rich systems of honorifics in languages such as Japanese do appear to reflect aspects of culture, but he was reluctant to accept a similar claim concerning rich systems of affectionate diminutives in Slavic languages, and on the whole he was skeptical of any search for direct correlations between language and social reality, a la Whorf. (Wierzbicka, 1992: 373) 
In answer, Wierzbicka continues to postulate the axiom that she outlined at the beginning of the article:

Language is a mirror of culture, as well as being a part of culture. (Ibid.)

In many scientific disciplines, functionalism does not recognize the differences in cultures. It is a typical feature of Parsons's "structural functionalism" (Parsons, 1952). Actually, functionalistic doctrines in social sciences are macrolevel and «holistic» theories establishing the general rules for interaction which do not have cultural, national and gender distinctions (at least from the sociological point of view). The genre approach was developed on this basis as a kind of this functional and institutional approach (Christie, 2005). In this sense SFL functions more like the macro-level of sociolinguistics.

The typical features of institutional approaches are as follows:

- a limited set of established institutional structures (e.g., genres), while their national uniqueness is not recognized; this means that genres do not have a national specificity and are common to all cultures

- $\quad$ socialisation is an extremely positive phenomenon; in the process of socialization a child should learn / learn by heart the established set of genres / institutions;

- there are institutional stakeholders (e.g., teachers) who impose this limited set of institutions (genres) as mandatory; but it would be better if they do it in a "dialogue" mode, reducing resistance and diversifying language skills. However, the set of institutions should remain unchanged.

The institutional approach has advantages and disadvantages. The advantage is the ability to achieve the main aim due to some reduction of secondary aims. However, all secondary goals can be removed and that this process can destroy some important dimensions of the development (see Fig.1).

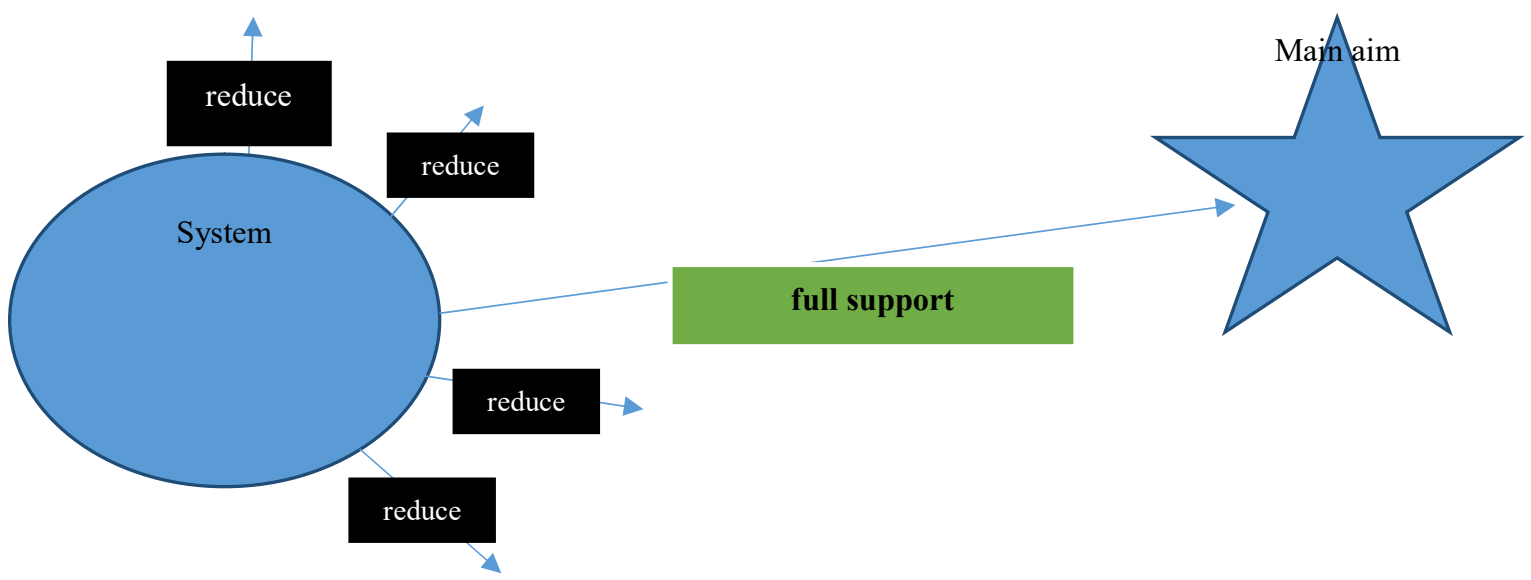

Figure 1. Advantages and disadvantages of the institutional approach (compiled from Tikhonov, 1999)

As we can see in Figure 1, when we work with institutional approaches, we do not get new resources (for example, development of the academic skills in English at an early age); we just redistribute the resources that we have and put all of them on one aim. However, our secondary aims can help us to adapt to new challenges. Thus, while we increase the targeting, we reduce the adaptability of the system (Tikhonov, 1999, 2005).

There are two basic SFL limits from the sociological point of view:

- Lack of diversity

- Disharmony of development (See Table 1)

Table 1. Limits of SFL as kind of institutional and functional approach from the sociological point of view

\begin{tabular}{lll}
\hline Problems with: & Features: & Examples: \\
\hline Lack of diversity & work with a variety (cultural, ethnic, gender) & $\begin{array}{l}\text { Stable scientific genres, mainly } \\
\text { Anglo-Saxon origin }\end{array}$ \\
\hline $\begin{array}{l}\text { Disharmony } \\
\text { development }\end{array}$ & $\begin{array}{l}\text { excessive concentration on one aim which can cause damage } \\
\text { to the most complex realization of human abilities and lead } \\
\text { to disharmony }\end{array}$ & $\begin{array}{l}\text { Teaching the academic scientific } \\
\text { genres to children at a rather early } \\
\text { age }\end{array}$ \\
\hline
\end{tabular}

Adapted from: Tikhonov, 1999; Pavenkova, 2001 
At the same time, the discussion about these limits is not new to SFL. Responses to both objections can be found in Vygotsky's theory. In his conception, Vygotsky provided idea of development of scientific concepts and claims that:

- $\quad$ scientific concepts are always developed by means of purposeful teaching and this is necessary;

- learning a foreign language (and consequently also the development of the academic genres in that language) promotes the development of the native language (and consequently also the academic genre's development in the native language) (Vygotsky, 1986).

Table 2. Limits of SFL as kind of institutional and functional approach from the sociological point of view and Vygotskian-related idea

\begin{tabular}{|c|c|c|c|}
\hline $\begin{array}{l}\text { Problems } \\
\text { with: }\end{array}$ & Features: & Examples: & Vygotsky's answers: \\
\hline $\begin{array}{l}\text { Lack of } \\
\text { diversity }\end{array}$ & $\begin{array}{l}\text { work with a variety } \\
\text { (cultural, ethnic, gender) }\end{array}$ & $\begin{array}{l}\text { Stable scientific } \\
\text { genres, mainly } \\
\text { Anglo-Saxon } \\
\text { origin }\end{array}$ & $\begin{array}{l}\text { «Success in learning a foreign language is contingent } \\
\text { on a certain degree of maturity in the native } \\
\text { language. The child can transfer to the new language } \\
\text { the system of meanings he already possesses in his } \\
\text { own. The reverse is also true-a foreign language } \\
\text { facilitates mastering the higher forms of the native } \\
\text { language. The child learns to see his language as one } \\
\text { particular system among many, to view its } \\
\text { phenomena under more general categories, and this } \\
\text { leads to awareness of his linguistic operations» (my } \\
\text { Italic) (Vygotsky, 1986:195-196) }\end{array}$ \\
\hline $\begin{array}{l}\text { Disharmony } \\
\text { of } \\
\text { development }\end{array}$ & $\begin{array}{l}\text { excessive concentration } \\
\text { on one aim which can } \\
\text { cause damage to the most } \\
\text { complex realization of } \\
\text { human abilities and led to } \\
\text { disharmony }\end{array}$ & $\begin{array}{l}\text { Teaching the } \\
\text { academic } \\
\text { scientific genres } \\
\text { to children at a } \\
\text { rather early age }\end{array}$ & $\begin{array}{l}\text { Early development of scientific concepts has a huge } \\
\text { value and develops a child`s thinking, «the greatest } \\
\text { value of scientific concepts for all mental } \\
\text { development of a child distinctly established» } \\
\text { (Vygotsky, 1934:197; this sentence is absent in } \\
\text { translation: Vygotsky, 1986) }\end{array}$ \\
\hline
\end{tabular}

Adapted from: Vygotsky, 1934; Vygotsky, 1986; Tikhonov, 1999; Pavenkova, 2001

However, Vygotsky's arguments based on the empirical Marxist psychology will not be completely accepted by us. Vygotsky established norms, and a deviation as pathology (Vygotsky, 1934: XV). It, of course, conducts to the restriction of diversity and responses to this diversity as an abnormality. It is a typical situation for Soviet Marxist psychology; we can observe this process in its further development (Yaroshevsky, 1996). In general, national and cultural distinctions could represent such an abnormality that they have to disappear in communism. Not incidentally, it was developed the concept of «Soviet people without nationalistic or ethnic ties» (Grenoble, 2003: 210). Therefore, the sociologists will continue to care about variety of genres in different cultures, because «functionally similar genres in different societies have their histories» (Luckmann, 2009: 278).

It is important that Vygotsky's concept concerned also children's age, which also was in some way abnormality and immaturity: childhood is only a preparation for future life, but not life itself (see e.g. Makarenko, 1986). This question is the cornerstone of Vygotsky's and Leo Tolstoy's discussion. While Tolstoy was concerned with violation of the natural process of the child's development and saw a threat in introduction of new scientific concepts ahead of time without an independent thinking, Vygotsky claims that it cannot do any harm (Vygotsky, 1986:150-152).

This discussion has long traditions in the Russian culture and means some opposition of rationalistic and more art/religious component in the child`s development. What has to be developed first of all: reason/mind or soul? We have to be concerned with the education of souls, and not just transfer of knowledge (e.g. Zlatoust, 1995). The modern Russian sociology of education and pedagogics may follow Tolstoy and cannot agree with the concept of childhood as an abnormal and previous period. It establishes the need of the full-fledged childhood with childish sports and fairy tales that develop art outlook and prepare for life better than scientific concepts and genres (e.g. see Balabanova, 2001).

The discussion about the advantages and disadvantages of the SFL conceptual background can continue infinitely as everything eventually depends on how it will be used. However, we have to consider that for Russia it looks as some step backward. On the one hand, it allows us to address our historical experience, but on the other hand, we do not know whether we will be able to take out a worthy lesson from this experience and to compensate the limits of this conception.

\subsection{Perspectives of SFL Development in the 21 th century: Halliday and World Englishes}

Before the end of the 20th century, SFL began to be considered as some kind of "outdated" old conception. It is connected with the general crisis of functional theories and institutional approaches in all social sciences. It seemed that 
they cannot give the answer to fast change of the world (Vorontsov et al., 1996). Latour's (2005) doctrine was involved in the pedagogical concepts that were originally based on SFL (see e.g. Veel, 1997; Dafouz \& Smit, 2014).

Actually Latour's conception is extremely negative. First of all, it is intended for criticism. Its advantage is the reflection about flexibility. However, it is insufficiently positive to be the basis for pedagogical concepts (Latour, 2005). In similar circumstances, sociology has preferred the conception of neoinstitutionalism that came from economy and economic sociology (Nort, 1997). Neoinstitutionalism considers the mechanism of institutional changes, and it is more adapted for the high speed of these changes that we have now.

Above we have shown that SFL is not the ordinary functionalistic social conception because it has the Marxist basis. I think the response to the discussion about teaching children at an early age (disharmony of development's limit) will not follow from Halliday. He continues to adhere to the concept in the spirit of Bernstein and Vygotsky because he sees the purpose overcoming of a class and social inequality in society.

But access to meanings is always limited, by inequalities in the social structure. Education is designed to increase people's access, and it does so by steering them through these evolutionary changes in turn: first we teach children written language, then we teach them standard language (or else both at the same time, depending on the circumstances); and then, perhaps, we may teach them world language (Halliday, 2003: 412)

Thus, he don't think about some ideas about childhood as an independent and valuable period in life. In this sense, he establishes another form of inequality - an inequality between children and adults; and from this point of view only adults are full-fledged and developed people (see also: Balabanova, 2001). For justice, it should be noted that Halliday wrote about children's language as resistance to adults (Halliday, 1978). But he has not a special emphasis on childhood as a valuable period in life.

The other limit - lack of diversity and English as an Anglo-Saxon influence- is a serious subject of discussion in modern Marxism. The distribution of the English language in the world can be non-voluntary and obligatory. It may conduct to new forms of inequality and humiliation. Besides the idea of internalization, joint construction of communism for people all over the world and other Marxist ideas, Halliday gives the answer in the form of anticolonialism:

At the same time, the "globe" that provides the context for global English is for the moment at least a world in which the voices of international capitalism, with their triumphalist rhetoric about the failure of people's first attempt to design something more humane, have learnt to exploit all the semogenic strategies that give language its enormous power. For corporations it comes as a bonus, inherited from colonial days, that the language of convenience in so many international contexts is none other than English (Halliday, 2003: 416)

First of all, Halliday suggests to refuse English as English became on service of corporations:

Many people would like to resist this dominance of English. The strategic response would seem to be: do away with English. Don't teach it, or do anything to perpetuate its standing in the community (Halliday, 2003: 416)

However, most likely it will not stop the process and will only cause damage to the population:

English is too deeply entrenched, and if people are deprived of the chance of learning it they are the ones who suffer (Halliday, 2003: 416)

Then, Halliday makes a distinction between the international and global English and develops the theory of two Englishes:

International English has expanded by becoming world Englishes, evolving so as to adapt to the meanings of other cultures. Global English has expanded - has become "global" - by taking over, or being taken over by, the new information technology, which means everything from email and the internet to mass media advertising, news reporting and all the other forms of political and commercial propaganda (Halliday, 2003: 416)

We could shift from global English to international Englishes and start creating the own project of English considering our mentality, culture, a genre and institutional variety. Moreover, we can use our option of English in advance of our ideas:

It seems that if you want to resist the exploitative power of English, you have to use English to do it... If African and Asian varieties of English are not simply vehicles for their regional cultures but also their communities' means of access to a culture that is already in effect global, those who speak and write these varieties are not constrained to be only consumers of the meanings of others; they can be 
creators of meanings, contributors to a global English which is also at the same time international. Meanings get reshaped, not by decree but through ongoing interaction in the semiotic contexts of daily life; and these have now become global contexts, even if those who participate in them are still only a fraction of the total population of the globe. Rather than trying to fight off global English, which at present seems to be rather a quixotic venture, those who seek to resist its baleful impact might do better to concentrate on transforming it, reshaping its meanings, and its meaning potential, in the way that the communities in the outer circle have already shown it can be done (Halliday, 2003: 416-417, my italic)

This moderate Marxist ideology of SFL can be apprehended positively in the Russian society and pedagogics. Also as well as Vygotsky's doctrine, it is an integral part of the Russian culture and it can be the cause of reduction of the strong concern and even public fear of the English language distribution. Moreover, Halliday's proposals open new perspectives of more fair work with English when nobody has imperious advantage. The Russians concerned with the presentation of their culture can create the own version of English - Russian English - and establish it as the linguistic standard for Russians and those who wishes to work with them.

\section{Discussion and Conclusion}

We analysed the ideological and theoretical principles and limits that are derived from the stages of systemic functional linguistics (SFL) development. The SFL pedagogical concept is changing due to the changes in the role of English. Firstly, English was taught as the native language to improve knowledge of the poorer classes. Then the task of nonEnglish speakers` adaptation in English-speaking countries has been added. Now we are talking about the non-native English language development in a non-English environment. Of course, such changes have led to changes in the ideological /theoretical basis of the concept.

The original ideological SFL concept was associated with the ideas of social justice and equality, equal opportunities. While we need to understand that, the most interesting ideas arose when the SFL representatives thought about the development of English as a native language and were connected with the overcoming of class distinctions. For example, in this case, the desire of a genre-based approach for the systematization of genres carries a risk of cultural contradictions and conflict of cultures. The combination of Marxism, which is inflexible from its philosophical nature with the same inflexible functionalism cannot be fully successful in the modern world.

In this regard, it should be noted that some of the basic theoretical SFL principles are still in the stage of formation, as SFL researchers (e.g. Veel, 1997) seek to avoid some rigidity of the classical institutional (genre) approach, which is in contradiction with the principles of diversity. Moreover the founder M. Halliday offered ideas for the organization of a flexible approach based on the basis of International English that "has expanded by becoming world Englishes, evolving so as to adapt to the meanings of other cultures" (Halliday, 2003: 416). Therefore, an SFL approach still needs some alterations to spread outside the Western world and conform to the new culture for it. Besides, we can think about proposals of Halliday's supporters to develop the own version of English for non-Western countries, considering its culture and mentality.

\section{References}

Alpatov, V.M. (2014). Language policy in Russia and in the world. Language policy and language conflicts in the modern world. Moscow.

Amuzie, G.L., \& Winke, P. (2009). Changes in language learning beliefs as a result of study abroad. System, 37(3), 366-379. doi: 10.1016/j.system.2009.02.011

Balabanova, M. (2001). Childhood as philosophical and pedagogical phenomenon [in Russian] SpB: Izdatelstvo RGPU.

Berger, P.L., \& Luckmann, T., (1991). The Social Construction of Reality. A Treatise in the Sociology of Knowledge. Penguin Books.

Bernstein, B. (1970). A socio-linguistic approach to socialisation: with some references to educability. Directions in Sociolinguistics (eds.) Gumperz, J. and Hymes, D., Holt, Rinehart and Winston, New York .

Bernstein, B. \& Henderson, D. (1969). Social class differences in the relevance of language to socialisation. Sociology, 3(1):1-20 doi: 10.1177/003803856900300101

Bernstein, B.B. (1999). Vertical and horizontal discourse: an essay. British Journal of Sociology of Education, 20, 157173(17).

Bjorkman, B. (2010). Spoken Lingua Franca English at a Swedish Technical University. Stockholm, Sweden: Department of English, Stockholm University

Blauberg, I. V. \& Yudin, B.G. (1972). Formation and essence of system approach [in Russian].Moscow: Nauka

Blommaert, J. (2010). The sociolinguistics of globalization. Cambridge: Cambridge University Press.

Blommaert, J., S Leppänen, P. Pahta \& T. Räisänen. (2012). Dangerous Multilingualism: Northern Perspectives on Order, Purity and Normality. London: Palgrave Macmillan 
Bruner J., (1987) Prologue to the English Edition. R. Rieber\& A. Carton (eds.). The collected works of L.S. Vygotsky. Vol. 1. Problems of general psychology. L.

Cenoz, J. (2009). Towards multilingual education: Basque educational research from an international perspective. Bristol: Multilingual Matters.

Cenoz, J., Genesee, F., \& Gorter, D. (2014). Critical Analysis of CLIL: Taking Stock and Looking Forward. Applied Linguistics 35 (3): 243-62. doi:10.1093/applin/amt011

Christie, F., \& Martin, J. R., (2009) eds.. Language, Knowledge and Pedagogy: Functional Linguistic and Sociological Perspectives. London, GBR: Continuum International Publishing.

Christie, F., eds. (2005) Genre and Institutions: Social Processes in the Workplace and School. London, GBR: Continuum International Publishing.

Coleman, J.A. (2006). English-medium teaching in European Higher Education. Language Teaching, 39(1), 1-14.

Cummins, J. (2000). Language, power, and pedagogy. Bilingual children in the crossfire. Clevedon, England: Multilingual Matters.

Cummins, J. J. (1984). Bilingualism and special education: issues in assessment and pedagogy. Clevedon: Multilingual Matters.

Cummins, J. \& Swain, M. (1986). Bilingualism in Education. N.Y.

Dafouz Milne E. \& Michele G. C. (eds). (2009). CLIL across Educational Levels. Madrid: Santillana Educación / Richmond Publishing

Dafouz Milne, E., Llinares, A., \& Morton, T. (2010). CLIL across contexts: A scaffolding framework for CLIL teacher education. View(z) Vienna WorkingPapers, $19(3$ - Special Issue), 12-20.

Dafouz, E. \& Smit, U. (2014). Towards a dynamic conceptual framework for English-medium education in multilingual university settings, Applied Linguistics, doi:10.1093/applin/amu034

Dafouz, E. (2014). Integrating content and language in European higher education: An overview of recurrent research concerns and pending issues. in Psaltou-Joycey, E. Agathopoulou and M. Mattheoudakis (eds) Cross-Curricular Approaches to Language Education. Cambridge: Cambridge Scholars. Pp. 289-304

Dafouz, E., Camacho, M. \& E. Urquia. (2014). 'Surely they can't do as well': a comparison of business students' academic performance in English-medium and Spanish-as-first-language-medium programmes, Language and Education, 28:3, 223-236, DOI: 10.1080/09500782.2013.808661

Dafouz, E., Hüttner, J. \& Smit, U. (2014). University teachers' beliefs on the roles of languages in higher education. Sociolinguistic Symposium 20, Jyvaskyla, June 17.

Dafouz, E., Hüttner, J., Nikula, T. \& Smit, U. (2014). English medium instruction (EMI) as a route to disciplinary language: university teachers' beliefs. AILA World Congress, Brisbane, August 13.

Dalton-Puffer, C, Nikula, T, \& Smit, U (Eds.). (2010). Language Use and Language Learning in CLIL Classrooms. Amsterdam: John Benjamins.

Dalton-Puffer, C. (2011). Content-and-Language Integrated Learning: From Practice to Principles? Annual Review of Applied Linguistics 31: 182-204. doi:10.1017/S0267190511000092.

Dalton-Puffer, C., \& Nikula, T. (2006). Pragmatics of Content-Based Instruction: Teacher and Student Directives in Finnish and Austrian Classrooms. Applied Linguistics, 27(2), 241-67. DOI:10.1093/applin/am1007

Dalton-Puffer, C., \& Nikula T. (2014). Content and Language Integrated Learning. The Language Learning Journal 42 (2): 117-22. doi:10.1080/09571736.2014.891370.

Dobson, A., Pérez Murillo, M. D., \& Johnstone, R. M. (2010). Bilingual education project Spain: Evaluation report. Madrid: Gobierno de España Ministerio de Educación \& British Council (Spain).

Europeans and Their Languages (2012). Special Eurobarometer 386/Wave EB 77.1

Europeans and Their Languages. (2006). Special Eurobarometer 243/Wave 64.3-TNS Opinion and Social European Commission

Fortanet-Gómez's, I. (2013). CLIL in Higher Education. Towards a Multilingual Language Policy. Immaculada Fortanet-Gómez Multilingual Matters: Bristol

Garfinkel, H. (1967). Studies in ethnomethodology. Englewood Cliffs, NJ: Prentice-Hall.

Giddens, A. (2001) Sociology. Cambridge: Polity Press

Goffman, E. (1981) Forms of talk. Oxford: Blackwell

Halliday, M.A.K. \& Hasan, R. 1985(1991). Language, context, and text: aspects of language in a social-semiotic perspective. Oxford University Press.

Halliday, M.A.K. (1978). Language as Social Semiotic. London. Edward Arnold.

Halliday, M.A.K. (1985). An Introduction to Functional Grammar. London. Edward Arnold. 
Halliday, M.A.K. (2003). Written language, standard language, global language. World Englishes, 22(4): $405-418$.

Hegel, G. W. F. (1969). Science of Logic, trans. A. V. Miller. London: George Allen \& Unwin.

Henderson, D. (1970). Contextual Specificity, Discretion, and Cognitive Socialization: With Special Reference to Language. Sociology. 4: 311-338, doi:10.1177/003803857000400302

Hnízdo, B. (2013). The global spread of English: Audi logo like a concept. Annual of Language and Politics and Politics of Identity. 7 (1), 103-112.

Holborow, M. (2006). Ideology and Language: Interconnections between Neo-liberalism and English; (Re-)Locating TESOL in an Age of Empire. Palgrave Macmillan

Hüttner, J., Dalton-Puffer, C., \& Smit, U. (2013). The Power of Beliefs: Lay Theories and Their Influence on the Implementation of CLIL Programmes. International Journal of Bilingual Education and Bilingualism 16 (3): $267-84$. doi:10.1080/13670050.2013.777385.

Kachru, B. (1986) The Alchemy of English: The Spread, Functions and Models of Non-native Englishes. Oxford: Pergamon Pre

Kerswill, P. (2007). Social class. The Routledge Companion to Sociolinguistics. Edited by Carmen Llamas, Louise Mullany and Peter Stockwell Routledge, 2007:51-62

Kreindler, I.T. (1984). The Non-Russian Languages and the Challenge of Russian: The Eastern versus the Western Tradition. Sociolinguistic Perspectives on Soviet National Languages: Their Past, Present and Future / Ed. by I. T. Kreindler. Berlin, etc.:Mouton de Gruyter.

Kumaravadivelu, B. (2006). Dangerous liaisons: globalization, empire and TESOL. In J.Edge (Ed.), (re)locating TESOL in an age of empire (pp. xii-xix). New York: Palgrave Macmillian

Labov, W. (1972). Sociolinguistic Patterns, Philadelphia, PA: University of Pennsylvania Press.

Latour B., (2005). Reassembling the Social. An Introduction to Actor-Network-Theory. Oxford University Press

Latour, B.\& Woolgar, St. (1986). Laboratory Life. The Construction of Scientific Facts. Princeton, New Jersey: Princeton University Press

Lorenzo, F., Casal, S. \& Moore, P. (2010). The Effects of Content and Language Integrated Learning in European Education: Key Findings from the Andalusian Bilingual Sections Evaluation Project. Applied Linguistics 31 (3): $418-$ 42. doi:10.1093/applin/amp041.

Lorenzo, F., Moore, P., \& Casal, S. (2011). On Complexity in Bilingual Research: The Causes, Effects, and Breadth of Content and Language Integrated Learning - a Reply to Bruton. Applied Linguistics 32 (4): 450-55. doi:10.1093/applin/amr025.

Luckmann, Th. (2009). Observations on the structure and function of communicative genres, Semiotica, 173 (1-4)

Makarenko, A.S., (1958). Works: In 7 vol. Vol.5. Moscow: NPA

Marriott, H. (2013). Multilingualism among University Staff: A Case Study of Language Management at an Australian University. International Journal of Multilingualism 10 (4): 454-68. doi:10.1080/14790718.2013.832126.

Martianova, N., Rubtcova, M., Pavenkov, O., Pavenkov, V., \& Martyanov, D. (2015). Deprofessionalisation as a performance management dysfunction: The case of inclusive education teachers in Russia. Asian Social Science, 11(18), 339-349.

Martin J. R. \& Williams G., (2004). Functional Sociolinguistic. An International Handbook of the Science of Language and Society. Edited by Ulrich Ammon, Norbert Dittmar, Klaus J. Mattheier\& Peter Trudgill 120- 129.

Martin, J. R., \& Rose, D. (2008). Genre relations: Mapping culture. London: Equinox.

Martin, J.R. \& Rose, D. (2007) Interacting with text: the role of dialogue in learning to read and write. Foreign Language Studies Journal, Beijing

Martin, J.R. (2009). Genre and language learning: A social semiotic perspective. Linguistics and Education, 20 (1):1021. doi: 10.1016/j.linged.2009.01.003

Marx, K. (1959). Economic and Philosophic Manuscripts of 1844. Progress Publishers, Moscow

Mehisto, P., \& Hiie Asser (2007). Stakeholder Perspectives: CLIL Programme Management in Estonia. International Journal of Bilingual Education and Bilingualism 10 (5): 683-701. doi:10.2167/beb466.0.

Menshikova, G. A., \& Pavenkova, M. V. (2001). Kirdina S.G. The institutional matrix and the developments of Russia. Sociological Journal, (1), 140-144.

Noel, E. (1972). Vvedenie v metodiku demoskopii. Moscow: Nauka

Nort D., (1997) Institutions and future. Voprosi filosofii 5(1)

Parsons T. (1952). Social System. Routledge

Parsons, T. \& Shils, E. (1951). Towards a General Theory of Action. Harvard University Press 
Pavenkova, M. (2001). An Institute and an Institutionality as Sociological Concepts. Vestnik St. Petersburg University. Ser. 6. Issue 3. doi:10.2139/ssrn. 2581550

Pavenkov, O., Rubtcova, M., Pavenkov, V., \& Vasilieva, E. (2015). The language of altruism: Corpus-based conceptualisation of social category for management sociology. Asian Social Science, 11(13), 289-297.

Pavenkov, V., Pavenkov, O., Rubtcova, M., \& Vasilieva, E. (2015). Representations of trust to public service in Russian Newspapers during election time: Corpus-based content analysis in public administration sociology. Mediterranean Journal of Social Sciences, 6(4S1), 436-444.

Pérez-Cañado, M. L. (2012). CLIL Research in Europe: Past, Present, and Future. International Journal of Bilingual Education and Bilingualism 15 (3): 315-41. doi:10.1080/13670050.2011.630064.

Phillipson, R. (2005). Linguistic Imperialism' 10 Years on: An Interview with Robert Phillipson: Robert Phillipson Talks to Sohail Karmani. ELT Journal 59 (3): 244-49. doi:10.1093/elt/cci045.

Proshina, Z.G., (2006). Russia English: status, attitudes, problems. The journal of Asia TEFL (3)2: 79-101

Proshina, Z.G., (2014). Russian English: Myth or Reality? Intercultural Communication Studies XXIII: 1

Ross, J.A. (1979). Language and the Mobilization of Ethnic Identity. Language and Ethnic Relations. London.

Rubtsova, M.V., (2007). Manageability: Sociological theoretical analysis of notions. Sotsiologicheskie Issledovaniya, $12,32-38$.

Rubtsova, M.V.V. (2011). Governmentability in interactions of subjects. Traditional and New Practices. Sotsiologicheskie Issledovaniya, 2, 46-53.

Rubtsova, M.V., Kapustkina, E., Karapetyan, R., Kovalev, I., \& Rasskazov, S. (2015). The social environment and business communication in English: A small-scale research on front-line staff performance in Russia, Spain and France. International Review of Management and Marketing, 5(4), 253-258.

Rubtcova, M. 2010. Sociological theory of manageability. St. Petersburg: Book House

Smit, U. \& Dafouz, E. (2012). Integrating content and language in higher education. An introduction to Englishmedium policies, conceptual issues and research practices across Europe. AILA Review 25: 1-12.

Smit, U. (2010). English as a Lingua Franca in Higher Education. A Longitudinal Study of Classroom Discourse. Berlin: De Gruyter Mouton.

Smith, K. (2004). Studying in an additional language: What is gained, what is lost and what is assessed? In Wilkinson (ed.), 78-93.

Tikhonov, A. V. (2010). The Russian Way of Modernization and a Choice of Strategy for Theoretical and Applied Studies of Forth Coming Problems. Russian Sociology on the Move Ed. by V. A. Mansurov. Moscow: RSS

Tikhonov, A.V. (1999). Sociology of Management. St. Petersburg: SPbGU

Tolstoy, L.N. (1948) Pedagogical works. Moscow: APN RSFSR

Vahtin N., \& Golovko E. (2004) Sociolinguistics and sociology of language. St. Petersburg: Academia

Veel, R. (1997). Learning how to mean - scientifically speaking: apprenticeship into scientific discourse in the secondary school. In F. Christie and J. R. Martin (eds.) Genre and Institutions: Social Processes in the Workplace and School, 161-195. London: Cassell.

Verenich, T.K. \& Kruglikova, E.A. (2012). American and English Borrowings in Russian: Blurring Ethnosocial Boundaries. Journal of Siberian Federal University. Humanities \& Social Sciences. 4(5), 535-542

Veresov, N. (2005). Marxist and non Marxist aspects of the cultural historical psychology of L. S. Vygotsky. Outlines. №1.

Vorontsov, A.V. \& Gromov, I.A. (1996). History of the western sociology. St. Petersburg: RGPU

Vygotsky, L. S. (1934). Thought and language. [in Russian] Moscow, Leningrad: SocEcGiz

Vygotsky, L. S. (1986). Thought and language. (A. Kozulin, Trans.) (Vol. Rev.). Cambridge, Mass.: MITPress.

Wenger, E. (1998). Communities of practice: learning, meaning, and identity. Cambridge: Cambridge University Press.

Wierzbicka, A. (1992). Semantics, Culture, and Cognition: Universal Human Concepts in Culture-Specific Configurations. Oxford University Press.

Wodak, R. (1988). Language power and ideology. John Benjamins Publishing Company.

Yaroshevsky, S. (1996). History of psychology. Moscow: Nauka. 